\title{
Effects of Pomegranate and Onion Peels Extracts on reducing weight and controlling diabetes in Obese Diabetic Rats
}

\author{
Marwa Ezz El-Din Ibrahim \\ Nutrition and Food Sciences Department, Faculty of Home Economics, \\ Helwan University
}

\begin{abstract}
The current study aimed to evaluate the effects of pomegranate peel extract (PPE) and onion peel extract (OPE) on body and fat weights; serum levels of liver enzymes, lipid profile, glucose, insulin and leptin hormones and on activities of renal tissue antioxidant enzymes and histopathology of kidneys in obese diabetic rats. Forty nine male Sprague Dawley rats were randomized into 7 equal groups $(n=7)$. Group 1 (negative control) was fed on basal diet, while the other 6 groups were fed on high-fat diet (HFD) for 4 weeks to induce acute obesity and hyperlipidemia. The obese rats were then rendered diabetic by intraperitoneal injection of alloxan $(120 \mathrm{mg} / \mathrm{kg} /$ day) for 5 days. On becoming diabetic, group 2 was kept obese diabetic as positive control and groups 3, 4, 5 and 6 were orally given PPE in doses 100 and $200 \mathrm{mg} / \mathrm{kg} \mathrm{b}$.wt and OPE in doses 100 and $200 \mathrm{mg} / \mathrm{kg} \mathrm{b}$.wt, respectively for 6 weeks. Group 7 was orally treated with Glibenclamide (standard antidiabetic drug) in a daily dose $5 \mathrm{mg} / \mathrm{kg}$ b.wt for 6 weeks. Blood samples were collected for biochemical analyses. Kidneys were dissected out for histopathology and renal homogenates were prepared to assay activities of tissue antioxidant enzymes. The results showed that oral administration of PPE and OPE to obese diabetic rats significantly reduced body and fat weights; decreased serum levels of aspartate aminotransferase (AST), alanine aminotransferase (ALT), alkaline phosphatase (ALP), total cholesterol, triglycerides and low density lipoprotein. It also decreased blood urea, creatinine, glucose and leptin hormone and increased in insulin levels. Both extracts increased activities of superoxide dismutase, glutathione peroxidase and catalase antioxidant enzymes in renal tissues and alleviated kidney histopathological lesions induced by diabetes. The results denote that pomegranate and onion peel extracts possess anti-obesity, antidiabetic effects, and consequences in obese diabetic rats. The study recommends that pomegranate and onion peels as waste products may be economically used for manufacture of safe and beneficial product for trials on obese diabetics patient.
\end{abstract}

Keywords: Pomegranate, Onion, Obesity, Diabetes, Biochemical analysis, Antioxidant.

\section{Introduction}

Obesity represents a fast growing serious health problem due to its positive correlation with increased prevalence of chronic heart diseases, diabetes mellitus and hypertension (Kumar et al., 2011 and Matsuda and Shimomura, 2013). There is a strong association between obesity and diabetes mellitus. Obesity is a key component of the insulin resistance syndrome in type 2 diabetes. Insulin resistance, mainly in liver and skeletal muscle, is a major risk factor for incidence of diabetes mellitus (Raza et al., 2013) and obesity plays a crucial role in insulin resistance and pathogenesis and development of diabetes mellitus (Hu et al. 2014).

Diabetes mellitus is a chronic metabolic disease characterized by hyperglycemia due to insulin deficiency, or insulin resistance, or both. Hyperglycemia occurs when the cells become unable to utilize glucose and/or the liver and skeletal muscles cannot store glycogen (Luis-Rodriguez et al., 2012). The increased extracellular and intracellular 
glucose concentrations lead to oxidative stress via increased production of reactive oxygen species (ROS) and sharp decrease in antioxidant body defenses (Lucchesi et al.,2013). The oxidative stress plays a key role in the onset and development of diabetes complications, mainly diabetic nephropathy (Li et al., 2014).

Pomegranate (Punica granatum L., Family Punicaceae) is an ancient fruit that grows on small trees cultivated throughout Mediterranean region of Southern Europe, the Middle East, tropical Africa and Southern Asia. Pomegranate peels (pericarps) are non edible waste parts of the fruit. Extracts of pomegranate peels were reported to attenuate hepatorenal toxicity induced by aluminum chloride in rats (Abdel Moneim et al., 2013) and to reduce oxidative stress induced by mercuric chloride in rats (Kumar et al., 2013). In addition, extracts of pomegranate peels were found to have anticancer against colon cancer in rats (Waly et al., 2012); antihyperglycemic, hepatoprotective and hypolipidemic (Kam et al., 2013 and Middha et al., 2013); antibacterial (Mehta et al., 2014); antiviral effects against human virus C (Reddey et al., 2014) and antioxidant and lipase inhibitory activities (Hadrich et al., 2014).

The extract of onion peels has been reported to enhance antioxidant status in aged rats (Park et al., 2007) and to produce vasorelaxant and hypotensive activities in rats (Naseri et al., 2008). Quercetin-rich onion peels extract when supplemented to diet induced anti-obesity effect via influencing adipokine expression in adipose tissues and inhibited adipogenesis in obese rats (Kim et al., 2012 and Moon et al., 2013). It was found that onion peels contain high amounts of quercetin which has been reported to have lipid lowering (anticholesterol), antithrombotic and insulin-sensitizing (antidiabetic) properties (Bae et al., 2014).

The main goal of this study was to assess the anti-obesity and antidiabetic activities of the ethanolic extracts of pomegranate and onion peels in obese diabetic rats.

\section{Materials and Methods}

\section{Plant materials:}

Pomegranate (Punica granatum L., Family Punicaceae) fruits and onion bulbs (Allium cepa, Family Amaryllidaceae) were purchased from a local market in Cairo, Egypt. The outer peels (pericarps) of pomegranate fruit and onion bulb were air dried, grinded using electric blender into a fine powder and kept till alcoholic extraction.

\section{Alloxan, Glibenclamide and kits:}

Alloxan was purchased from El-Gomhoryia Company for Chemicals, Egypt; as a white powder packed bottles containing $25 \mathrm{~g}$ alloxan monohydrate. Glibenclamide (Doanil ${ }^{\circledR} 5 \mathrm{mg}$ ) was purchased from Sanofi Synthelabo Company as tablets each containing $5 \mathrm{mg}$ Glibenclamide (potent hypoglycemic drug). Glucose enzymatic kits for estimating blood glucose and radioimmunoassay kits for leptin and insulin hormones were purchased from Gamma Trade Company, Egypt. The other biochemical kits were procured from Biodiagnostics Company, Dokki, Egypt.

Rats:

Forty nine adult male Sprague Dawley rats of $175-185 \mathrm{~g}$ body weight and 8-10 weeks old were used in this study. Animals were obtained from the Laboratory Animal Colony, Agricultural Research Center, Egypt. Rats were housed in a well ventilated animal room under standard conditions $\left(24^{\circ} \mathrm{C}\right.$ temperature and $50 \%$ relative humidity) $)$. Basal diet and water were provided ad libitum. The experiment on rats was carried out according to the National regulations on animal welfare and Institutional Animal Ethical Committee (IAEC), NRC, Dokki, Egypt. 


\section{Egypt. J. of Nutrition and Health Vol. 10 No. 1 (2015)}

\section{Preparation of basal diet:}

The dietary supply of protein, fat, carbohydrates, vitamins and minerals was prepared recommended by Reeves et al., (1993). Basal diet consisted of $20 \%$ protein, $10 \%$ sucrose, $4.7 \%$ fat, $2 \%$ choline chloride, $1 \%$ vitamin mixture, $3.5 \%$ salt mixture and $5 \%$ fibers (cellulose). The remainder was corn starch up to $100 \%$.

\section{Preparation of ethanolic extracts:}

Four hundred grams $(400 \mathrm{~g})$ of the dried powder of pomegranate peels and similar amount from onion peels were socked in 2 liter of $90 \%$ ethanol and kept in a refrigerator with daily shaking for 5 days. This was followed by percolation for 5 to 7 times till complete exhaustion. The ethanolic extracts were concentrated under reduced pressure using a vacuum Rotatory evaporator at $50{ }^{\circ} \mathrm{C}$ temperature. Starting plant material of $400 \mathrm{~g}$ of pomegranate peel and onion peel yielded 41.8 and $38.5 \mathrm{~g}$ semisolid extract, respectively. Twenty grams of each semisolid extract were dissolved in $98 \mathrm{ml}$ distilled water and $2 \mathrm{ml}$ of Tween 80 (suspending agent) to obtain 20\% ethanolic extract (concentration of $200 \mathrm{mg} / \mathrm{ml}$ ) as described by Shalaby and Hamowieh (2010). The tested doses of both extracts were 100 and $200 \mathrm{mg} / \mathrm{kg} \mathrm{b.wt}$, corresponding to 0.5 and $1 \mathrm{ml}$ of the liquid extract, respectively.

\section{Induction of obesity and diabetes:}

Obesity was induced by feeding rats on high-fat diet (HFD) for 4 weeks which supplies $45 \%$ calories from pig fat (lard). This obese model in rats closely resembles the reality of obesity in humans according to Bhatt et al. (2006). The obese rats were rendered diabetic by intraperitoneal injection of alloxan in a dose of $120 \mathrm{mg} / \mathrm{kg} / \mathrm{day}$ for 5 days according to Ashok et al. (2007). Thereafter, fasting blood glucose levels were estimated, and rats with blood glucose level higher than $180 \mathrm{mg} / \mathrm{dL}$ were only used in the study.

\section{Experiment design:}

Forty nine adult Sprague Dawley rats were randomized into 7 groups, of 7 rats each. Group 1 was fed on basal diet (negative control), while the other 6 groups were fed on HFD for 4 weeks to induce obesity. There after, obese rats were rendered diabetic by intraperitoneal injection of alloxan $(120 \mathrm{mg} / \mathrm{kg} /$ day) for 5 days. After induction of diabetes, group 2 was kept obese diabetic and continued as positive control, while groups 3, 4, 5 and 6 were orally given the ethanolic extract of pomegranate peel in doses of 100 and $200 \mathrm{mg} / \mathrm{kg}$ and onion peel extract in doses of 100 and $200 \mathrm{mg} / \mathrm{kg}$, respectively, daily for 6 weeks. Group 7 was orally given Glibenclamide in a dose of $5 \mathrm{mg} / \mathrm{kg}$ b.wt for 6 weeks. At the end of experiment, the rats were weighed and body fats were carefully removed and weighed. The adiposity index(Ad.I) was calculated by dividing the total weight of mesenteric, visceral, epididymal and retroperitoneal adipose tissues by the body weight and multiplied by 100 i.e. Ad.I = fat weight/body weight x100 according to Pichon et al. (2006). Rats were anethetized by prolonged exposure to ether and blood samples were withdrawn for separating the serum which was kept frozen until biochemical analyses. Kidneys were dissected out, divided into two portions; one portion was used for preparing renal homogenates to assay the activity of tissue antioxidant enzymes, the other portion of kidneys was preserved in $10 \%$ formalin solution till processed for histopathological examination.

\section{Biochemical analyses:}

Serum aspartate aminotransferase and alanine aminotransferase (Bergmeyer et al., 1978), alkaline phosphatase (Roy, 1970), total cholesterol (Richmond, 1973), triglycerides (Friedewald et al., 1972) and high density lipoprotein cholesterol (Richmond, 1973) were chemically determined using specific diagnostic kits and measured on a spectrophotometer. Low density lipoprotein cholesterol was calculated according to Friedewald formula: LDL-c = TC (TG/5) - HDL-C). Blood urea nitrogen (Patton and Crouch, 1977), uric acid (Fossati et al., 1980) and creatinine (Husdan and Rapoport, 1968) concentrations were chemically determined. Blood glucose was determined using glucose enzymatic kit according to Siest et al. (1981). Insulin was estimated using specific antibody radioimmunoassay (RIA) kit according to Yallow and Bauman (1983). Leptin hormone was determined using enzyme-linked immunosorbent assay (ELISA) according to Xiong et al. (2005). 


\section{Marwa Ezz El-Din Ibrahim}

Renal antioxidant enzymes:

One gram of kidney tissue was washed with ice-cooled $0.9 \% \mathrm{NaCl}$ solution and homogenized in $100 \mathrm{ml}$ of icecooled $1.5 \%$ solution of potassium chloride and $50 \mathrm{mMol}$ of potassium phosphate buffer solution $(\mathrm{pH} 7.4)$ to yield $10 \%$ homogenate (WN). Kidney homogenates were centrifuged at $8000 \mathrm{rpm}$ for 10 minutes at $4^{\circ} \mathrm{C}$ and the supernatants were used to assay the activity of antioxidant enzymes superoxide dismutase (SOD), glutathione peroxidase (GPx), and catalase (CAT) according to Spitz and Oberley (1989), Paglia and Valentaine (1979) and Sinha (1972) respectively.

\section{Histological procedure:}

Kidneys of sacrificed rats were taken and fixed in $10 \%$ neutral formalin solution. The fixed specimens were then trimmed, washed and dehydrated in ascending grades of alcohol. The specimens were then embedded in paraffin, cross sectioned (cs) at 4-6 microns thickness, stained with Hematoxylen and Eosin and then examined microscopically (Carleton, 1976).

\section{Statistical analysis:}

Data were presented as mean \pm SE. Statistical comparisons between different groups were performed using oneway analysis of variance (ANOVA) test followed by Duncan multiple range tests (Snedecor and Cochran, 1986). Statistical analyses were performed using computerized program (SPSS version 15, Chicago, USA).

\section{Results}

Feeding rats on high-fat diet (HFD) for 4 weeks caused significant increases $(P<0.05)$ in body weight, fat weight and adiposity index when compared to the negative control group. Oral administration of pomegranate peel extract (PPE) at 100 and $200 \mathrm{mg} / \mathrm{kg}$ and onion peel extract (OPE) at the same doses to obese diabetic rats for 6 weeks resulted in significant decreases $(P<0.05)$ in body weight, fat weight and adiposity index when compared to the positive control group. Glibenclamide also decreased body and fat weights and adiposity index as recorded in Table 1.

Table 1:

Body weight (B.wt), fat weight (F.wt) and adiposity index (Ad.I) in obese diabetic rats at the end of the experiment. ( $n=7$ rats.)

\begin{tabular}{|c|c|c|c|}
\hline $\begin{array}{l}\text { Parameters } \\
\text { Groups }\end{array}$ & $\begin{array}{l}\text { B.wt } \\
\text { (gm) }\end{array}$ & $\begin{array}{l}\text { F.wt } \\
(\mathrm{gm})\end{array}$ & $\begin{array}{l}\text { Ad.I } \\
(\%)\end{array}$ \\
\hline $\begin{array}{l}\text { Group 1: } \\
\text { Negative control }\end{array}$ & $245.0 \pm 8.0^{e}$ & $6.55 \pm 0.12^{\mathrm{d}}$ & $2.67 \pm 0.10^{d}$ \\
\hline $\begin{array}{l}\text { Group 2: } \\
\text { Positive control }\end{array}$ & $300.0 \pm 9.5^{a}$ & $14.50 \pm 0.52^{a}$ & $4.83 \pm 0.17^{\mathrm{a}}$ \\
\hline $\begin{array}{l}\text { Group 3: } \\
\text { PPE (100 mg/kg) }\end{array}$ & $288.0 \pm 7.5^{b}$ & $8.80 \pm 0.45^{c}$ & $3.05 \pm 0.14^{c}$ \\
\hline $\begin{array}{l}\text { Group } 4: \\
\text { PPE }(200 \mathrm{mg} / \mathrm{kg})\end{array}$ & $285.0 \pm 6.0^{b}$ & $8.00 \pm 0.37^{c}$ & $2.80 \pm 0.12^{c}$ \\
\hline $\begin{array}{l}\text { Group 5: } \\
\text { OPE (100 mg/kg) }\end{array}$ & $280.0 \pm 7.5^{c}$ & $10.50 \pm 0.30^{b}$ & $3.75 \pm 0.15^{b}$ \\
\hline $\begin{array}{l}\text { Group 6: } \\
\text { OPE }(200 \mathrm{mg} / \mathrm{kg})\end{array}$ & $283.0 \pm 6.5^{c}$ & $9.80 \pm 0.15^{b}$ & $3.46 \pm 0.12^{c}$ \\
\hline $\begin{array}{l}\text { Group 7: } \\
\text { Glibenclamide } \\
(5 \mathrm{mg} / \mathrm{kg})\end{array}$ & $260.0 \pm 5.0^{d}$ & $7.00 \pm 0.15^{\mathrm{d}}$ & $2.69 \pm 0.10^{d}$ \\
\hline
\end{tabular}

Means \pm SE with different letters superscripts $(a, b, c, d)$ in the same column are significant at $P<0.05$ using one way ANOVA test. 


\section{Egypt. J. of Nutrition and Health Vol. 10 No. 1 (2015)}

Rats fed on HFD for 4 weeks had significant increases $(P<0.05)$ in serum levels of liver enzymes aspartate aminotransferase (AST), alanine aminotransferase (ALT), and alkaline phosphatase (ALP) (recording $108 \pm 0.17^{\mathrm{a}}, 84$ $\pm 0.35^{\mathrm{a}}$ and $104 \pm 0.73^{\mathrm{a}} \mathrm{U} / \mathrm{L}$, respectively) when compared with negative control rats fed on basal diet (recording 60 $\pm 0.43^{\mathrm{d}}, 38 \pm 0.65^{\mathrm{d}}$ and $84 \pm 0.23^{\mathrm{d}} \mathrm{U} / \mathrm{L}$, respectively). Both PPE and OPE in doses 100 and $200 \mathrm{mg} / \mathrm{kg}$ when given to obese diabetic rats significantly lowered $(P<0.05)$ the high serum levels of AST, ALT and ALP enzymes when compared to the positive control group. PPE in doses $200 \mathrm{mg} / \mathrm{kg}$ have most significantly decrease $(P<0.05)$ of AST, ALT and ALP enzymes (recording $74 \pm 0.15^{c}, 60 \pm 0.30^{c}$ and $82 \pm 0.47^{c} \mathrm{U} / \mathrm{L}$, respectively) compared to OPE at the same doses $200 \mathrm{mg} / \mathrm{kg}$ (recording $89 \pm 0.22^{\mathrm{b}}, 72 \pm 0.53^{\mathrm{b}}$ and $89 \pm 0.81^{\mathrm{b}} \mathrm{U} / \mathrm{L}$, respectively). Glibenclamide also significantly decrease $(P<0.05)$ serum levels of AST, ALT and ALP enzymes (recording $52 \pm 0.15^{\mathrm{d}}, 40 \pm 0.93^{\mathrm{d}}$ and 72 $\pm 0.51^{\mathrm{d}} \mathrm{U} / \mathrm{L}$, respectively) as illustrated in Fig. 1 .

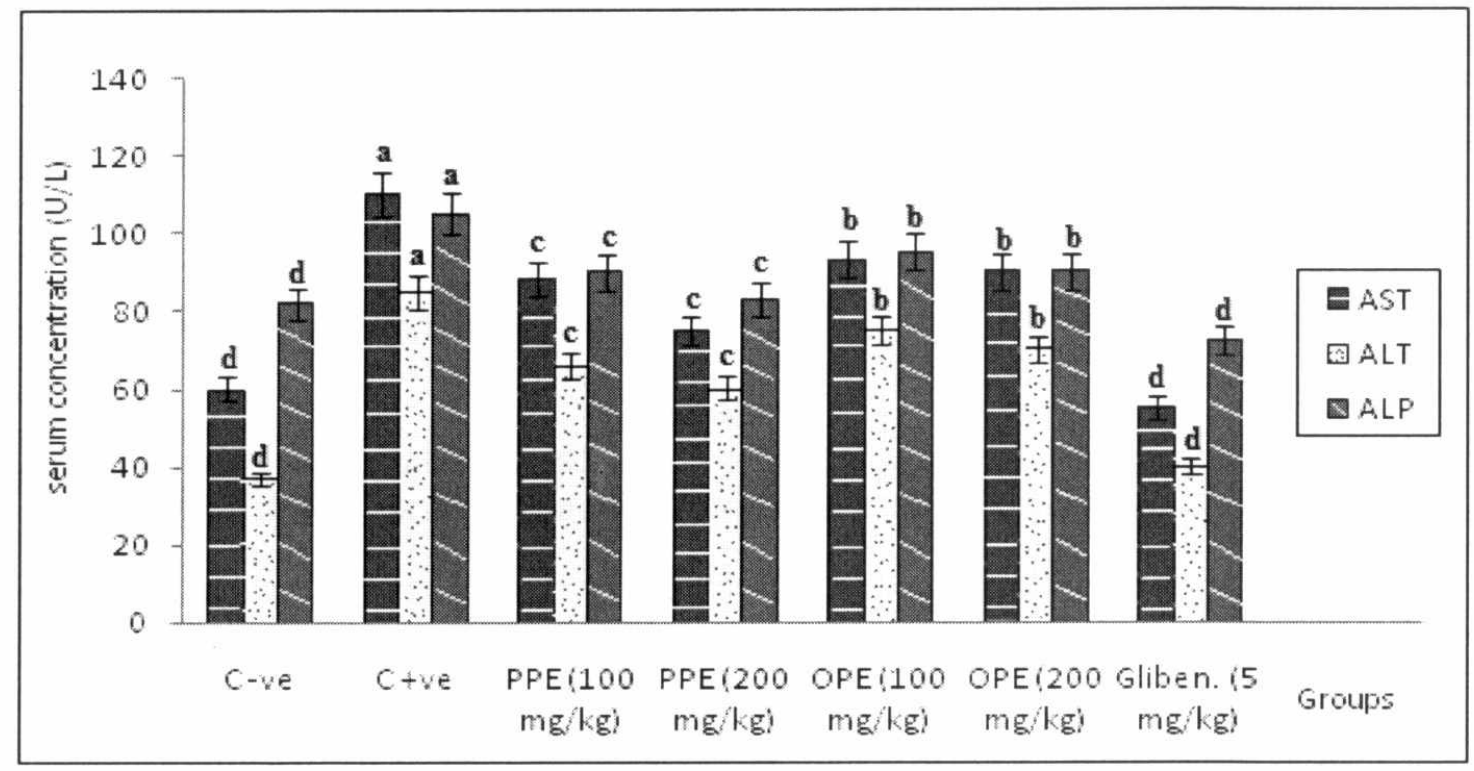

Fig. 1: Serum levels of aspartate aminotransferase (AST), alanine aminotransferase (ALT) and alkaline phosphatase (ALP) enzymes in obese diabetic rats at the end of the experiment.

Feeding of rats on HFD for 4 weeks produced significant elevation at $(P<0.05)$ in serum levels of total cholesterol TC $\left(136 \pm 2.82^{\mathrm{a}} \mathrm{mg} / \mathrm{dL}\right)$ and triglycerides TG $\left(144 \pm 3.13^{\mathrm{a}} \mathrm{mg} / \mathrm{dL}\right)$ when compared to negative control rats fed on basal diet (recording $96 \pm 1.25^{\mathrm{d}}$ and $112 \pm 2.591^{\mathrm{d}} \mathrm{mg} / \mathrm{dL}$, respectively). Oral administration PPE and OPE in doses of 100 and $200 \mathrm{mg} / \mathrm{kg}$ to obese diabetic rats for 6 weeks significantly decreased $(P<0.05)$ the elevated levels of serum TC and TG when compared to the positive control group. TC and TG (recording $120 \pm 4.11^{\mathrm{c}}$ and $100 \pm 3.421^{\mathrm{c}} \mathrm{mg} / \mathrm{dL}$, respectively) for PPE at dose $200 \mathrm{mg} / \mathrm{kg}$, while OPE (recording $130 \pm 1.31^{\mathrm{b}}$ and $114 \pm 2.12^{\mathrm{b}} \mathrm{mg} / \mathrm{dL}$, respectively) . Glibenclamide also induced significant decreases $(P<0.05)$ in high serum levels of TC and TG (recording $100 \pm 4.11^{\mathrm{d}}$ and $108 \pm 2.721^{\mathrm{d}}$ $\mathrm{mg} / \mathrm{dL}$, respectively) as demonstrated in Fig 2.

The results denoted that feeding of rats on HFD for 4 weeks caused a significant $(P<0.05)$ decrease in serum level of high density lipoprotein (HDL), increases significant $(P<0.05)$ in both low density lipoprotein (LDL), and atherogenic index ( $\mathrm{Al})$ when compared to negative control rats. Oral administration of PPE and OPE in doses of 100 and $200 \mathrm{mg} / \mathrm{kg}$ to obese diabetic rats for 6 weeks significantly increased $(P<0.05)$ serum HDL-C, significant decreased $(P$ $<0.05$ ) both LDL-c and Al when compared with the positive control groups. Glibenclamide also significant increased $(P$ $<0.05$ ) serum HDL-C and significant decreased $(P<0.05)$ both LDL-C and Al as depicted in Table 2. 


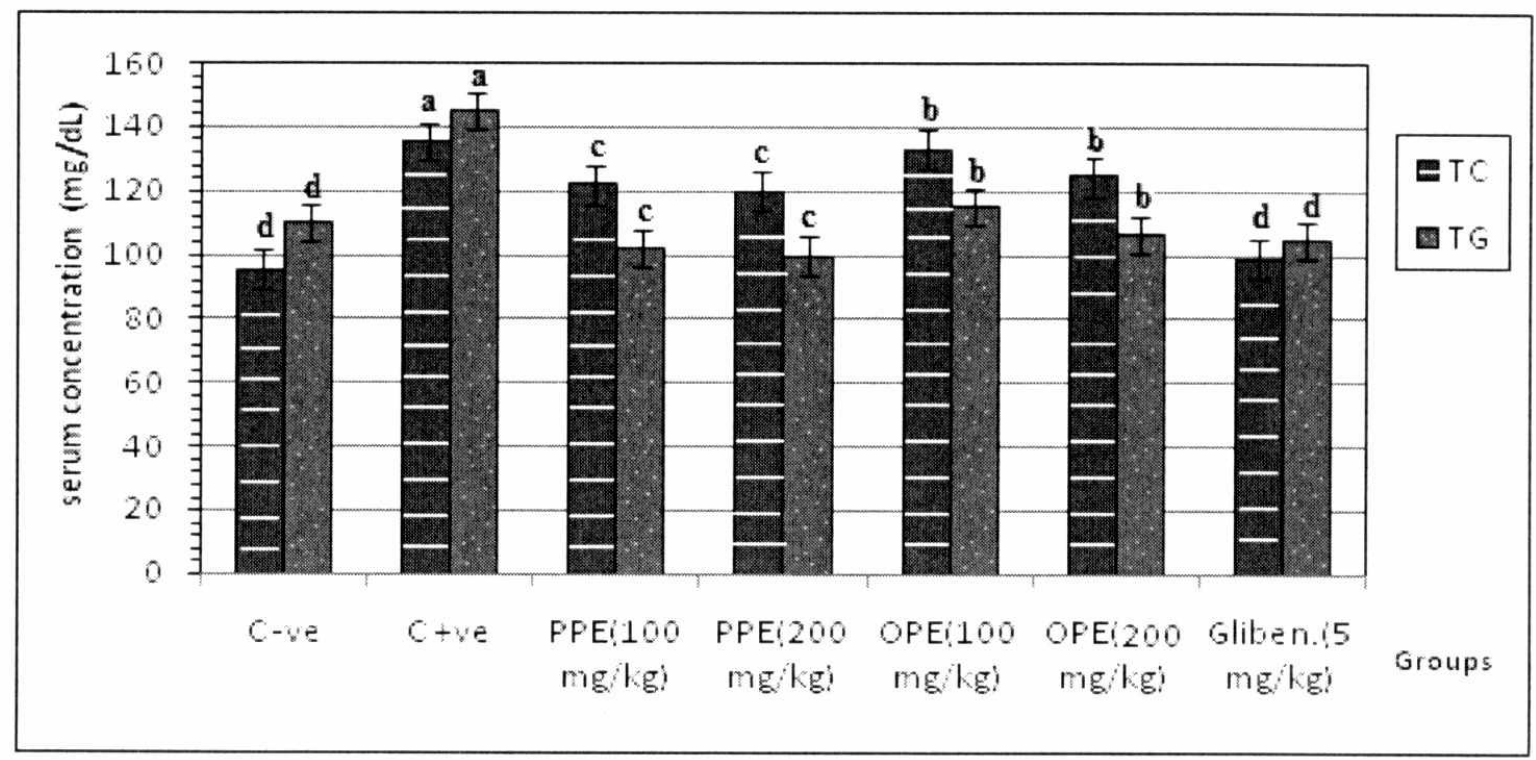

Fig. 2: Serum total cholesterol (TC) and triglycerides (TG) in obese diabetic rats at the end of the experiment.

Table 2:

Serum levels of high density lipoprotein (HDL-C), low density lipoprotein (LDL-c) cholesterol and atherogenic index (AI) in obese diabetic rats at the end of the experiment. ( $n=7$ rats).

\begin{tabular}{|c|c|c|c|}
\hline $\begin{array}{l}\text { Parameters } \\
\text { Groups }\end{array}$ & $\begin{array}{l}\text { HDL-c } \\
(\mathrm{mg} / \mathrm{dL})\end{array}$ & $\begin{array}{l}\text { LDL-c } \\
(\mathrm{mg} / \mathrm{dL})\end{array}$ & $\begin{array}{c}\mathrm{Al} \\
(\mathrm{LDL}-\mathrm{c} / \mathrm{HDL}-\mathrm{C})\end{array}$ \\
\hline $\begin{array}{l}\text { Group 1: } \\
\text { Negative control }\end{array}$ & $79.00 \pm 3.5^{a}$ & $17.50 \pm 0.2^{d}$ & 0.221 \\
\hline $\begin{array}{l}\text { Group 2: } \\
\text { Positive control }\end{array}$ & $52.00 \pm 2.1^{d}$ & $39.50 \pm 0.5^{a}$ & 0.759 \\
\hline $\begin{array}{l}\text { Group 3: } \\
\text { PPE (100 mg/kg ) }\end{array}$ & $76 . .3 \pm 3.8^{b}$ & $28.50 \pm 0.1^{b}$ & 0.373 \\
\hline $\begin{array}{l}\text { Group 4: } \\
\text { PPE (200 mg/kg) }\end{array}$ & $75.50 \pm 4.7^{b}$ & $27.00 \pm 0.4^{b}$ & 0.357 \\
\hline $\begin{array}{l}\text { Group 5: } \\
\text { OPE (100 mg/kg) }\end{array}$ & $63.00 \pm 3.6^{c}$ & $23.40 \pm 0.3^{c}$ & 0.371 \\
\hline $\begin{array}{l}\text { Group 6: } \\
\text { OPE (200 mg/kg) }\end{array}$ & $65.00 \pm 2.5^{c}$ & $21.40 \pm 0.1^{c}$ & 0.329 \\
\hline $\begin{array}{l}\text { Group 7: } \\
\text { Glibenclamide }(5 \mathrm{~m}\end{array}$ & $78.50 \pm 2.2^{b}$ & $19.00 \pm 0.3^{c}$ & 0.242 \\
\hline
\end{tabular}

Data in Table 3 showed that rats fed on HFD for 4 weeks had significantly $(P<0.05)$ increased blood glucose and leptin hormone and decreased insulin hormone levels when compared to rats fed on basal diet (negative control group). 
Egypt. J. of Nutrition and Health Vol. 10 No. 1 (2015)

PPE and OPE when orally given in doses 100 and $200 \mathrm{mg} \mathrm{kg}$ to obese diabetic rats for 6 weeks significantly decreased $(P<0.05)$ serum glucose and leptin hormone and increased insulin levels when compared with positive control rats. Glibenclamide also significantly decreased $(P<0.05)$ serum levels of glucose and leptin hormone and increased insulin levels.

Rats fed HFD for 4 weeks had significant increases $(P<0.05)$ in blood urea (BUN) and creatinine $(\mathrm{Cr})$ levels when compared to control rats. PPE and OPE when given orally to obese diabetic rats in doses of 100 and $200 \mathrm{mg} / \mathrm{kg}$ significantly decreased $(P<0.05)$ the high serum levels of $\mathrm{BUN}$ and $\mathrm{Cr}$ as compared to the positive control group. Glibenclamide also significantly decreased $(P<0.05)$ BUN and $\mathrm{Cr}$ concentrations in the serum $($ Table 4$)$.

Table 3:

Blood glucose (BG) and leptin and insulin hormones levels in obese diabetic rats at the end of the experiment. ( $n=7$ rats).

\begin{tabular}{|c|c|c|c|}
\hline $\begin{array}{l}\text { Parameters } \\
\text { Groups }\end{array}$ & $\begin{array}{c}\text { BG } \\
(\mathrm{mg} / \mathrm{dl})\end{array}$ & $\begin{array}{l}\text { Leptin } \\
(\mathrm{ng} / \mathrm{ml})\end{array}$ & $\begin{array}{l}\text { Insulin } \\
\text { (ng/ml) }\end{array}$ \\
\hline $\begin{array}{l}\text { Group 1: } \\
\text { Negative control }\end{array}$ & $200.5 \pm 3.0^{e}$ & $2.65 \pm 0.12^{d}$ & $2.88 \pm 0.15^{a}$ \\
\hline $\begin{array}{l}\text { Group 2: } \\
\text { Positive control }\end{array}$ & $255.0 \pm 4.0^{a}$ & $6.90 \pm 0.13^{a}$ & $0.89 \pm 0.13^{\mathrm{d}}$ \\
\hline $\begin{array}{l}\text { Group 3: } \\
\text { PPE }(100 \mathrm{mg} / \mathrm{kg})\end{array}$ & $165.5 \pm 2.0^{c}$ & $3.55 \pm 0.16^{c}$ & $2.52 \pm 0.24^{b}$ \\
\hline $\begin{array}{l}\text { Group 4: } \\
\text { PPE }(200 \mathrm{mg} / \mathrm{kg})\end{array}$ & $163.5 \pm 3.0^{c}$ & $3.35 \pm 0.17^{c}$ & $2.33 \pm 0.12^{b}$ \\
\hline $\begin{array}{l}\text { Group 5: } \\
\text { OPE (100 mg/kg) }\end{array}$ & $189.5 \pm 3.0^{b}$ & $4.90 \pm 0.12^{b}$ & $1.62 \pm 0.14^{c}$ \\
\hline $\begin{array}{l}\text { Group 6: } \\
\text { OPE }(200 \text { mg/kg) }\end{array}$ & $186.5 \pm 4.0^{b}$ & $4.75 \pm 0.13^{b}$ & $1.58 \pm 0.14^{c}$ \\
\hline $\begin{array}{l}\text { Group } 7: \\
\text { Glibenclamide } \\
(5 \mathrm{mg} / \mathrm{kg})\end{array}$ & $140.0 \pm 3.0^{d}$ & $3.45 \pm 0.15^{b}$ & $2.75 \pm 0.14^{c}$ \\
\hline
\end{tabular}

Means \pm SE with different letters superscripts $(a, b, c, d)$ in the same column are significantly different at $P<0.05$ using one way ANOVA test. 
Table 4:

Blood urea nitrogen (BUN), uric acid (UA) and creatinine $(\mathrm{Cr}$ ) levels in obese diabetic rats at the end of the experiment. ( $n=7$ rats)

\begin{tabular}{|c|c|c|c|}
\hline $\begin{array}{l}\text { Parameters } \\
\text { Groups }\end{array}$ & $\begin{array}{l}\text { BUN } \\
(\mathrm{mg} / \mathrm{dL})\end{array}$ & $\begin{array}{c}\text { UA } \\
(\mathrm{mg} / \mathrm{dL})\end{array}$ & $\begin{array}{c}\mathrm{Cr} \\
(\mathrm{mg} / \mathrm{dL})\end{array}$ \\
\hline $\begin{array}{l}\text { Group 1: } \\
\text { Normal control }\end{array}$ & $35.8 \pm 2.1^{\mathrm{d}}$ & $1.60 \pm 0.01^{\mathrm{a}}$ & $0.65 \pm 0.01^{d}$ \\
\hline $\begin{array}{l}\text { Group 2: } \\
\text { Positive control }\end{array}$ & $66.0 \pm 4.3^{a}$ & $1.62 \pm 0.06^{\mathrm{a}}$ & $1.84 \pm 0.04^{a}$ \\
\hline $\begin{array}{l}\text { Group 3: } \\
\text { PPE (100 mg/kg) }\end{array}$ & $47.1 \pm 2.6^{c}$ & $1.64 \pm 0.02^{\mathrm{a}}$ & $0.96 \pm 0.02^{c}$ \\
\hline $\begin{array}{l}\text { Group 4: } \\
\text { PPE (200 mg/kg) }\end{array}$ & $41.8 \pm 3.3^{c}$ & $1.63 \pm 0.04^{\mathrm{a}}$ & $0.82 \pm 0.02^{c}$ \\
\hline $\begin{array}{l}\text { Group 5: } \\
\text { OPE (100 mg/kg) }\end{array}$ & $56.5 \pm 4.1^{b}$ & $1.60 \pm 0.01^{a}$ & $1.27 \pm 0.03^{b}$ \\
\hline $\begin{array}{l}\text { Group 6: } \\
\text { OPE }(200 \text { mg/kg) }\end{array}$ & $55.4 \pm 3.5^{b}$ & $1.62 \pm 0.05^{\mathrm{a}}$ & $1.24 \pm 0.02^{b}$ \\
\hline $\begin{array}{l}\text { Group } 7 \text { : } \\
\text { Glibenclamide } \\
(5 \mathrm{mg} / \mathrm{kg})\end{array}$ & $40.6 \pm 2.8^{c}$ & $1.63 \pm 0.01^{\mathrm{a}}$ & $0.92 \pm 0.01^{c}$ \\
\hline
\end{tabular}

Means \pm SE with different letters superscripts $(a, b, c, d)$ in the same column are significantly different at $P<0.05$ using one way ANOVA test.

Feeding HFD to rats for 4 weeks significantly decreased $(P<0.05)$ renal tissue levels of superoxide dismutase (SOD), glutathione peroxidase (GPx) and catalase (CAT) antioxidant enzymes when compared to rats fed on basal diet. Oral administration of PPE and OPE in doses of 100 and $200 \mathrm{mg} / \mathrm{kg}$ to obese diabetic rats for 6 weeks increased the activity of renal tissue of SOD, GPx and CAT enzymes when compared with the positive control group. Glibenclamide also significantly increased $(P<0.05)$ activities of SOD and CAT enzymes as depicted in Table 5.

Histopathological examination of renal cortex of normal control rats showed normal histological structure of renal parenchyma (renal corpuscles and tubules) as illustrated in Fig. (3). Kidneys of obese diabetic rats revealed marked necrosis and degeneration of renal tubules (Fig. 4). Examination of kidney section following oral administration of pomegranate peel extract in a dose of $200 \mathrm{mg} / \mathrm{kg}$ to obese diabetic rats for 6 weeks showed almost normal histological structure of renal parenchyma as demonstrated in Fig (5). In obese diabetic rats administered with $200 \mathrm{mg} / \mathrm{kg}$ of onion peel extract, the microscopical examination of kidney sections revealed moderate congestion of blood vessels in between renal tubules as shown in Fig (6). 
Egypt. J. of Nutrition and Health Vol. 10 No. 1 (2015)

Table 5:

Aof tissue superoxide dismutase (SOD), glutathione peroxidase (GPx) and catalase (CAT) antioxidant enzymes in obese diabetic rats at the end of the experiment. ( $n=7$ rats).

\begin{tabular}{|c|c|c|c|}
\hline $\begin{array}{l}\text { Parameters } \\
\text { Groups }\end{array}$ & $\begin{array}{c}\text { SOD } \\
\text { (U/mg protein) }\end{array}$ & $\begin{array}{c}\text { GPx } \\
\text { (nmol/min/mg protein) }\end{array}$ & $\begin{array}{c}\text { CAT } \\
(\mathrm{nmol} / \mathrm{min} / \mathrm{mg} \text { protein) }\end{array}$ \\
\hline $\begin{array}{l}\text { Group 1: } \\
\text { Negative control }\end{array}$ & $59.50 \pm 2.11^{a}$ & $0.94 \pm 0.04^{a}$ & $0.188 \pm 0.01^{a}$ \\
\hline $\begin{array}{l}\text { Group 2: } \\
\text { Positive control }\end{array}$ & $36.50 \pm 2.18^{d}$ & $0.18 \pm 0.01^{\mathrm{d}}$ & $0.135 \pm 0.02^{\mathrm{d}}$ \\
\hline $\begin{array}{l}\text { Group 3: } \\
\text { PPE (100 mg/kg ) }\end{array}$ & $53.74 \pm 3.46^{b}$ & $0.75 \pm 0.03^{b}$ & $0.175 \pm 0.02^{b}$ \\
\hline $\begin{array}{l}\text { Group 4: } \\
\text { PPE (200 mg/kg) }\end{array}$ & $54.95 \pm 2.58^{b}$ & $0.79 \pm 0.03^{b}$ & $0.178 \pm 0.01^{b}$ \\
\hline $\begin{array}{l}\text { Group 5: } \\
\text { OPE (100 mg/kg) }\end{array}$ & $46.25 \pm 2.73^{c}$ & $0.57 \pm 0.01^{c}$ & $0.145 \pm 0.02^{c}$ \\
\hline $\begin{array}{l}\text { Group 6: } \\
\text { OPE (200 mg/kg) }\end{array}$ & $45.25 \pm 2.73^{c}$ & $0.56 \pm 0.02^{c}$ & $0.147 \pm 0.01^{c}$ \\
\hline $\begin{array}{l}\text { Group 7: } \\
\text { Glibenclamide } \\
(5 \mathrm{mg} / \mathrm{kg})\end{array}$ & $52.25 \pm 2.73^{b}$ & $0.29 \pm 0.01^{\mathrm{d}}$ & $0.183 \pm 0.01^{b}$ \\
\hline
\end{tabular}

Means \pm SE with different letters superscripts $(a, b, c, d)$ in the same column are Significantly different at $P<0.05$ using one way ANOVA test.

Unit of $\mathrm{GPx}=\mathrm{nmol}$ of $\mathrm{GSH}$ utilized $/ \mathrm{min} / \mathrm{mg}$ protein.

Unit of $\mathrm{CAT}=\mathrm{nmol}$ of $\mathrm{H}_{2} \mathrm{O}_{2}$ utilized/min/mg protein. 


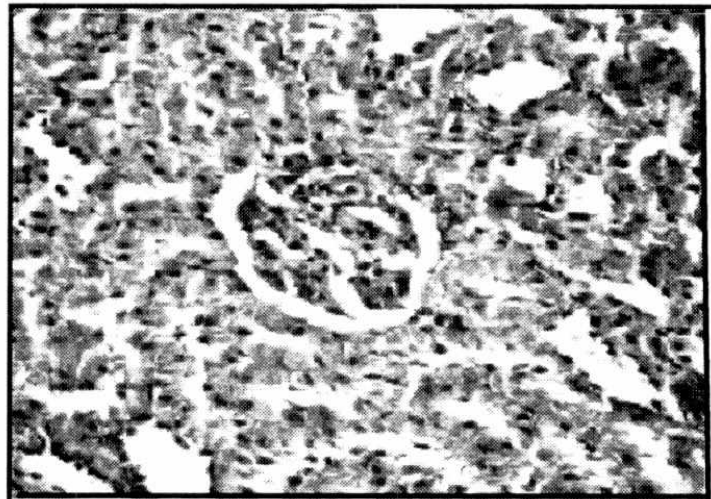

Fig.(3)

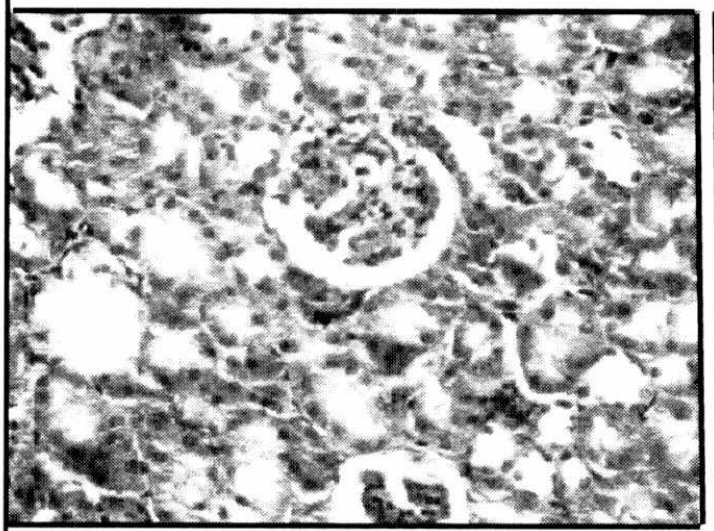

Fig.(5)

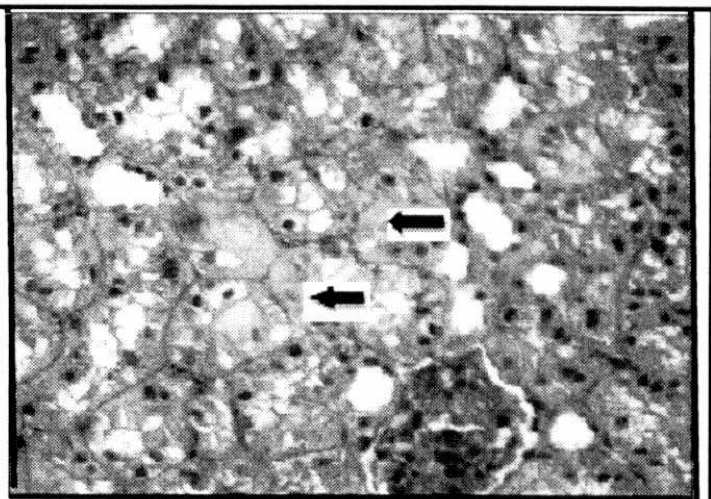

Fig.(4)

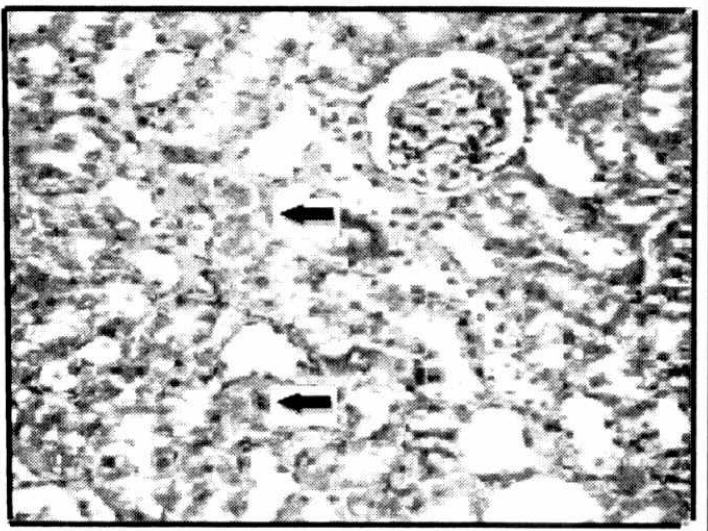

Fig. (6)

Fig. 3: C.S. of a kidney cortex of normal control rat showing normal architecture of renal parenchyma (glomeruli and tubules). (H\&E X 200).

Fig. 4: C.S.in a kidney cortex of obese diabetic rat showing marked necrosis and fatty degeneration of renal tubules (arrows). (H\&E X 200).

Fig. 5: C.S.in a kidney cortex of obese diabetic rat given orally pomegranate peel extract at $200 \mathrm{mg} / \mathrm{kg}$ showing almost normal histological structure of renal parenchyma. (H\&E X 200).

Fig. 6: C.S.in a kidney cortex of obese diabetic rat given orally onion peel extract at $200 \mathrm{mg} / \mathrm{kg}$ showing moderate congestion of blood vessels in-between renal tubules (arrows). (H\&E X 200). 


\section{Egypt. J. of Nutrition and Health Vol. 10 No. 1 (2015)}

\section{Discussion}

Fruits and vegetables which possess anti-obesity and antidiabetic effects have recently gained much attention, especially those with low toxicity. The biological value of fruits and vegetables depends on their bioactive constituents such as saponins, tannins, anthocyanins, flavonoids, polyphenols, diterpenes, triterpenes and other phytochemicals (Patel et al., 2012).

Results of the present study denoted that pomegranate peel extract (PPE) when given orally to obese diabetic rats reduced body and fat weights and decreased adiposity index. Measurement of adipose (fat) tissue weight has been used as a valid index in obesity studies. The anti-obesity activity of PPE is reported for the first time in this study. However, Neyrinck et al. (2013) reported that feeding pomegranate peel to obese mice counteracted the inflammatory markers in adipose tissue, denoting its anti-inflammatory activity. Onion peel extract (OPE) induced a potent reduction in body weight and fat in obese diabetic rats. The effect of OPE agreed with the previous reports of Kim et al. (2012) and Moon et al., (2013). The previous authors concluded that OPE supplemented to diet induced its effect via influencing adipokine expression in adipose tissues in obese rats.

The mechanism(s) underlying the anti-obesity effect of PPE and OPE could be possibly explained by their hyperinsulinimic effect evident in the present study in obese diabetic rats. Hyperinsulinemia is a common features of obesity (Raza et al., 2013). Other mechanism of anti-obesity activity of PPE and OPE could be due to decreased level of leptin hormone reported in the present study. In this concern, Friedman (2011) mentioned that leptin hormone is secreted by adipose tissue in proportion to its weight (mass). When body fat mass decreases, the plasma leptin levels decreases till fat mass is restored. On this basis, the decreased fat weight in obese diabetic rats given PPE or OPE could be possibly attributed to the reported low serum leptin level (hypoleptinemia).

The hepatoprotection and antihyperlipidemia of PPE and OPE reported in this study were evident from the significant decreases in the elevated serum levels of liver enzymes (AST, ALT and ALP), total cholesterol and triglycerides in obese diabetic rats. These findings agreed with the previous reports of Middha et al., (2013) for PPE and of Bae et al., (2014) for OPE. The hepatoprotective activity of PPE and OPE could be possibly attributed to their antioxidant effect that previously reported by Middha et al., (2013), Abdel Moneim et al., (2013) and Kumar et al., (2013) for PPE and by Park et al., (2007) for OPE. The hypolipidemic effect of PPE could be due to its contents of polyphenols which inhibit the intestinal absorption of cholesterol and so reduce serum cholesterol levels (Middha et al., 2013). Concerning OPE, its hypolipidemic activity was explained by its high content of quercetin which has been reported to have lipid lowering properties (Bae et al., 2014).

In this study, blood glucose levels were decreased significantly by PPE. The hypoglycemic effect of PPE agreed with the previous reports of Parmar and Kar (2008); Kam et al., 2013; Middha et al., (2013) and Benihani, et al., (2013). This effect was attributed to the presence of punicalagin, ellagic and gallic acids in PPE which have been reported to possess antidiabetic action (Parmar and Kar, 2008). The hypoglycemic activity of OPE reported in this study was similar to that demonstrated by Bae et al., (2014) who concluded that onion peels contain high amounts of quercetin that induces insulin-sensitizing (antidiabetic) properties

The present results denoted that oral administration of PPE and OPE to obese diabetic rats caused hyperinsulinemia. The hyperinsulinemic effect of PPE and OPE was similar to that reported by Parmar and Kar, (2008) for PPE and by Bae et al., (2014) for OPE in rats. The increased insulin secretion following administration of PPE and OPE to obese rats, in this study, might be the possible mechanism of their antidiabetic activity. 
The current results revealed that rats fed on HFD had high serum leptin hormone level when compared with rats fed on basal diet. This result was in accordance with that reported by Huang et al. (2004). Leptin plays a key role in regulating energy intake and energy expenditure and the level of circulating leptin is proportional to the total amount of body fats. PPE and OPE significantly decreased serum leptin levels in obese diabetic rats. No references were available on the effect of PPE and OPE on serum leptin level in rats. The effect of PPE and OPE on serum leptin level in rats is performed for the first time in this study in obese diabetic rat model.

The activity of antioxidant enzymes (SOD, GPx and CAT) increased in renal tissues of obese diabetic rats fed on PPE and OPE. PPE and OPE given orally to obese diabetic rats caused an anti-oxidant activity. The antioxidant effect of PPE and OPE was in accordance with the previous findings of Hadrich et al., (2014) for PPE and of Park et al., (2007) for OPE.

In conclusion, extracts of pomegranate and onion peels may reduce weight and helps to control diabetes and may have hypolipidemic, hepatoprotective, nephroprotective and antioxidant effects in obese diabetic rats. The study recommends that pomegranate and onion peels considered as waste products may be used for manufacture of a product that could be tried on obese diabetic patients.

\section{Acknowledgment}

I wish to thank Dr. Doaa Ezz-Eldin Ibrahim Soliman, lecturer of Histology and Histochemistry, Zoology and Entomology Department, Faculty of Science, Helwan University, for helping the histological examination in this study. 


\section{Egypt. J. of Nutrition and Health Vol. 10 No. 1 (2015)}

\section{References}

Abdel Moneim, A.E.; Othman, M.S.; Mahmoud, S.M. and El-Deib, K.M. (2013):

Pomegranate peel attenuates aluminum-induced hepatorenal toxicity. Toxicol. Mech. Methods; 23(8): 624-633.

Ashok, D.C.; Shrimant, N.P; Panadeep, M.G. and Akalpita, U.A. (2007):

Optimization of alloxan dose is essential to induce stable diabetes mellitus for long period. Asian J. Biochem.; 2(6): $402-408$.

Bae, C.R.; Park, Y.K. and Cha, Y.S. (2014):

Quercetin-rich onion peel extract suppresses adipogenesis by down-regulating adipogenic transcription factors and gene expression in 3T3-L1 adipocytes. J. Sci. Food Agric.; 94(13):2655-2660.

Benihani, S.; Swedan, S. and Alguraan, Z. (2013):

Pomegranate and diabetes type 2. Nutr. Res.; 33(5):341-348.

Bergmeyer, H.U.; Schreiber, P. and Wahlefeld, A.W. (1978):

Optimization of methods for aspartate and alanine aminotransferase. Clin. Chem.; 24: 58-61.

Bhatt, B.A.; Dube, J.J.; Dedousis, N.; Reider, J.A. and O'Doherty, R.M. (2006):

Diet- induced obesity and acute hyperlipidemia reduce I kappa B alpha levels in rat skeletal muscle in a fibertype dependent manner. Am. J. Physiol.; 290:233-240.

Carleton, H. (1976):

Carleton's Histological technique. The 4th Edition, London, Oxford University press New York, Toronto. Page 53-59.

Fossati, P.; Prencipe, L. and Berti, G. (1980):

Use of 3, 5 dichloro-2-hydroxyl benzene sulfonic acid /4-amylphenazone chromogenic system in direct enzymatic assay of uric acid in serum and urine. Clin. Chem.; 26: 227-231.

Friedewald, W.T.; Levy, R.I. and Frederickson, D.S. (1972):

Estimation of plasma or serum low density lipoprotein cholesterol concentration without use of ultracentrifuge. Clin. Chem.; 18: 499-502.

Friedman, J.M. (2011):

Leptin and the regulation of body weight. The Keio J. Med.; 60:1-9.

Hadrich, F.; Cher, S.; Gargouri, Y.T. and Adel, S. (2014):

Antioxidant and lipase inhibitory activities and essential oil composition of pomegranate peel extracts. J. Oleo. Sci.; 63(5): 515-525.

Hu, C.; Su, Q.; Li, F.; Zhang, G.; Sun, D.; Han, H and Hu, S. (2014):

Duodenal-jejunal bypass improves glucose homeostasis in association with decreased proinflammatory response and activation of JNK in the liver and adipose tissue in a T2DM rat model. Obes. Surg.; 24(9): 1453-1462. 


\section{Marwa Ezz El-Din Ibrahim}

Huang, B.W.; Chiang, M.T.; Yao, H.T. and Chiang W. (2004):

The effect of high- fat and high-fructose diets on glucose tolerance, plasma lipid and leptin levels in rats. Diabet.

Obes. Metab..; 6(2): 120-126.

Husdan, H. and Rapoport, A. (1968):

Estimation of creatinine by Jaffe reaction method. Clin. Chem.; 14: 222-228.

Kam, A.; Li, K.M.; Razmovski-Naumovski.; Nammi, S.; Shi, J.; Chan, K. and Li, G.Q. (2013):

A comparative study on the inhibitory effects of different parts and chemical constituents of pomegranate on aamylase and a-glucosidase. Phytothr. Res.; 27:1614-1620.

Kim, O.Y.; Lee, S.M.; Do, H.; Moon, J.; Lee, K.H.; Cha, Y.J. and Shin, M.J.(2012):

Influence of quercetin-rich onion peel extracts on adipokine expression in the visceral adipose tissue of rats. Phytother. Res.; 26(3):432-437.

Kumar, D.; Singh, S.; Singh, A.K. and Rizvi, S.I. (2013):

Pomegranate (Punica granatum) peel extract provides protection against mercuric chloride-induced oxidative stress in Wistar strain rats. Pharm. Biol.; 51(4): 441-446.

Kumar, S.; Alagawadi, K.R. and Rao, M.R. (2011):

Effect of Argyreia speciosa root extract on cafeteria diet-induced obesity in rats. Ind. J. Pharmacol.; 43:163-167.

Li, W.; Wang, G.; Lu, X.; Jiang, Y.; Xu, L. and Zhao, X. (2014):

Lycopene ameliorates renal function in rats with streptozotocin-induced diabetes. Int. J. Clin. Exper. Pathol.; 7(8): 5008-5015.

Lucchesi, A.N.; Freitas, N.T.; Cassettari, L.L.; Marques, S.E. and Spadella, C.T. (2013):

Diabetes mellitus triggers oxidative stress in the liver of alloxan-treated rats: A mechanism for diabetic chronic liver disease. Acta Cir. Bras.; 28(7): 502-508.

Luis-Rodríguez, D.; Martínez-Castelao, A.; Gorriz, J.L.; De-Alvaro, F. and Navarro-Gonzalez, J.F. (2012):

Pathophysiological role and therapeutic implications of inflammation in diabetic nephropathy. World J. Diab.; 15: 7-18.

Matsuda, M. and Shimomura, I. (2013):

Increased oxidative stress in obesity: implications for metabolic syndrome, diabetes, hypertension, dyslipidemia, atherosclerosis and cancer. Obest. Res. Clin. Pract.; 7(5):330-341.

Mehta, V.V.; Rajesh, G.; Rao, A. and Shenoy, R. (2014):

Antimicrobial efficacy of Punica granatum mesocarp, Nelumbo nucifera leaf, Psidium guajava leaf and Coffea Canephora extracts on common oral pathogens. J. Clin. Diag. Res.; 7(8): 65-68.

Middha. S.K.; Usha, T. and Pande, V. (2013):

A review on antihyperglycemic and hepatoprotective activities of eco-friendly Punica granatum peel waste. Evid. Based Complement, Alternat. Med.; 656172. Doi: 10.1155/2013/656172. 


\section{Egypt. J. of Nutrition and Health Vol. 10 No. 1 (2015)}

Moon, J.' Do, H.J.; Kim, O.Y. and Shin, M.J. (2013):

Antiobesity effects of quercetin- richonion peel extract on the differentiation of 3T3-L1 preadipocytes and the adipogenesis in high fat-fed rats. Food Chem. Toxicol.; 58: 347-354.

Naseri, M.K.; Arabian, M.; Badavi, M. and Ahangarpour, A. (2008):

Vasorelaxant and hypotensive effects of Allium cepa peel hydro-alcoholic extract in rat. Pak. J. Biol. Sci.; 11(12): 1569-1575.

Neyrinck, A.M.; Van, V.F.; Bindels, L.B.; De Backer, F.; Can, P.D. and Delzenne, N.M. (2013):

Polyphenol-rich extract of pomegranate peel alleviates tissue inflammation and hypercholesterolemia in high-fat

diet-induced obese mice: potential implication of the gut microbiota. Br. J. Nutri.; 109(5): 802-809.

Paglia, D.F. and Valentaine, W.N. (1979):

Studies on glutathione and glutathione characterization of erythrocytes glutathione peroxidase. J. Lab. Clin. Med.; 70:158-169.

Park, J., Kim, J. and Kim, M.K. (2007):

Onion flesh and onion peel enhance antioxidant status in aged rats. J. Nutr. Vitaminol.; 53:21-29.

Parmar, H.S. and Kar, A. (2008):

Medicinal values of fruit peels from Citrus sinensis, Punica granatum, and Musa paradisiaca with respect to alterations in tissue lipid peroxidation and serum concentration of glucose, insulin, and thyroid hormones. J Med Food, 11(2): 376-381.

Patel, D.; Prasad, S.; Kumar, R. and Hemalatha, S. (2012):

An overview on antidiabetic medicinal plants having insulin mimetic property. Asian Pac.J. Trop. Biomed.;

2(4):320330.

Patton, C. J. and Crouch S.R. (1977):

Enzymatic colorimetric method for determination of urea in serum. Anal. Chem.; 49: 464-465.

Pichon, L.; Huneau, J.F.; Fromentin, G. and Tome, D. (2006):

A high - protein, high fat, carbohydrate - free diet reduces energy intake, hepatic lipogenesis and adiposity. J. Nutr.; 136: 1256-1260.

Raza, H.; John, A. and Howarth, F.C. (2013):

Increased metabolic stress in Zucker diabetic fatty rat kidney and pancreas. Cell Physiol. Biochem.; 32(6): 16101620 .

Reddy, B.U.; Mullick, R.; Kumar, A.; Sudha, G.; Srinivasan, N. and Das, S. (2014):

Small molecule inhibitors of HCV replication from pomegranate. Sci. Res.; 4:5411-5415

Reeves, P.G.; Nielson, F.H. and Fahmy, G.C. (1993):

AIN-93 purified diets for laboratory rodents: final report of the American Institute of Nutrition ad hoc writing committee on the reformulation of the AIN-76A rodent diet. J. Nutri.; 123: 1939-1951. 


\section{Marwa Ezz El-Din Ibrahim}

Richmond, N. (1973):

Colorimetric determination of total cholesterol and high density lipoprotein cholesterol (HDL-c). Clin. Chem.; 19:1350-1356.

Roy, S.E. (1970):

Colorimetric determination of serum alkaline phosphatase. Clin. Chem., 16: 431-432

Shalaby, M.A. and Hamowieh, A.R. (2010):

Safety and efficacy of Zingiber officinale roots on fertility of male diabetic rats. Food Chem. Toxicol.; 48:29202924.

Siest, G.; Henny, F. and Schiele, F. (1981):

Enzymatic determination of glucose. interpret. Exam. Lab.; 2: 206-213.

Sinha, K.A. (1972):

Colorimetric assay of catalase enzyme. Anal. Biochem.; 47: 328-330.

Snedecor, G.W. and Cochran, W.G. (1986):

Statistical Methods, 7th Edition, lowa State University Press, Ames, USA, Page 90-99.

Spitz, D.R. and Oberley, L.W. (1989):

An assay for superoxide dismutase activity in mammalian tissue homogenates. Anal. Biochem.; 179: 8-18.

Waly, M.I., Ali, A.; Guizani, N.; Al-Rawahi, A.S.; Farooq, S.A. and Raman, M.S. (2012):

Pomegranate (Punica granatum) peel extract efficacy as a dietary antioxidant against Azoxymethane-induced colon cancer in rat. Asian Pac. J. Cancer Prev.; 13(8):4051-4055.

Xiong, Y.; Shen, L.; Liu, K. J.; Tso, P.; Xiong, Y.; Wang, G.; Woods, S.C. and Liu, K. (2005):

(Anti-obesity and antihyperglycemic effects of ginsenoside Rb1 in rats. Diabetes; 59: 2505-2512.

Yallow, R. and Bauman, W.A. (1983):

Plasma insulin in health and disease. In: Diabetes Mellitus: Theory and Practice. Editors: Ellenberg, M. and Rifkin, H., Excerpta Medica; 15:119-120. 
Egypt. J. of Nutrition and Health Vol. 10 No. 1 (2015)

\author{
أثر خلاصات قشور الرمان وقشور البصل على انقاص الوزن وضبط مستوى السكر

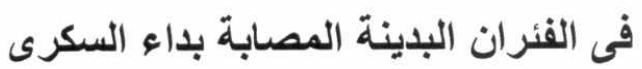

\author{
مروة عز الدين ابراهيم سليمان
}

قسم التغذية وعلوم الأطعمة ـ كلية الاقتصاد المنزلى - جامعة حلوان

$$
\text { الملخص العربى }
$$

استهذف هذا البحث تقييم تأثير خلاصات قشّور الرمان والبصل على وزن الجسم، ووزن دهون الجسم، إنزيمات الكبد، صورة دهون

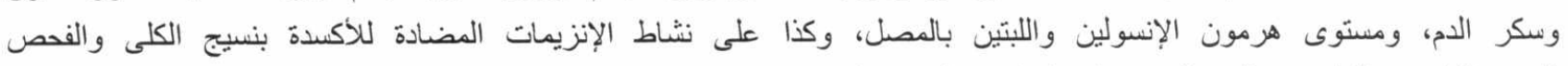

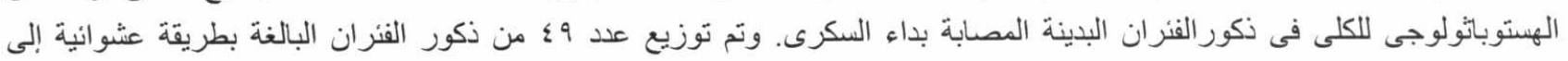

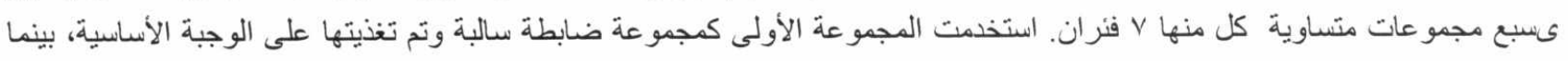

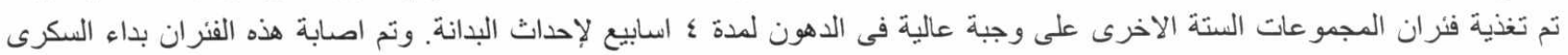

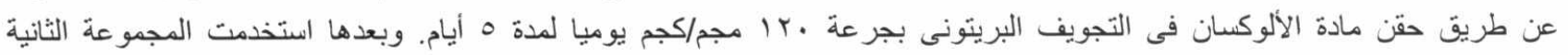

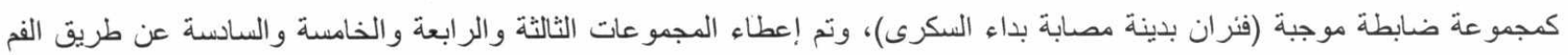

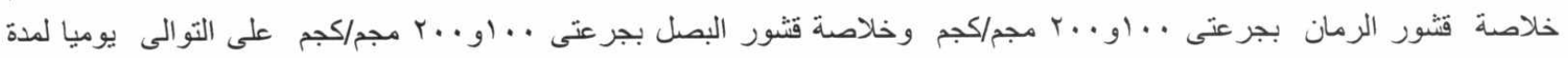

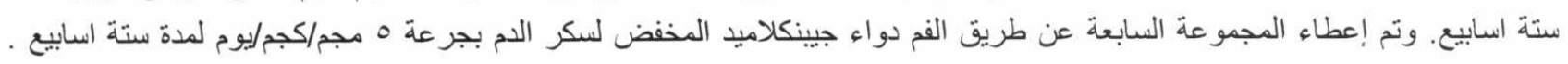

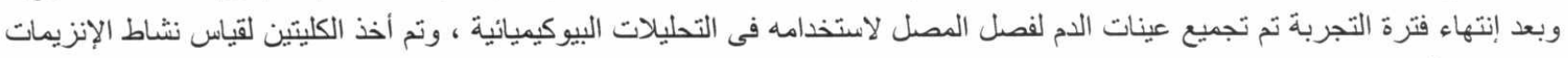

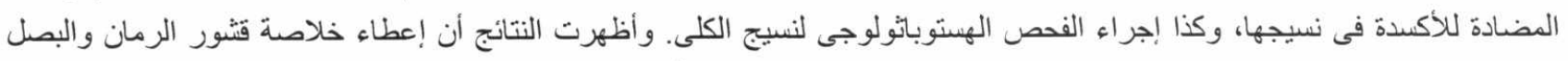

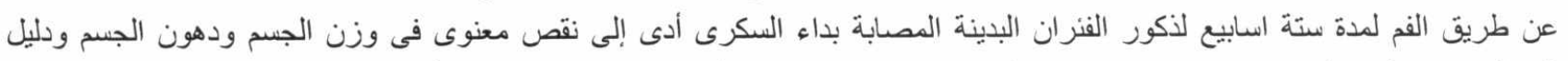

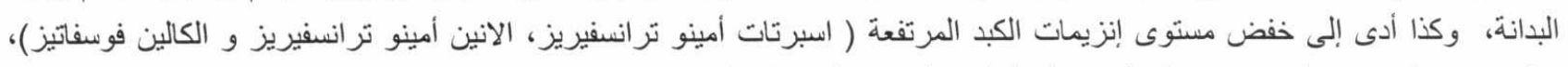

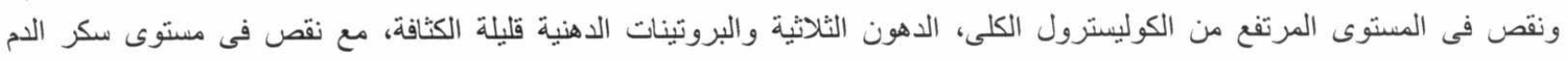

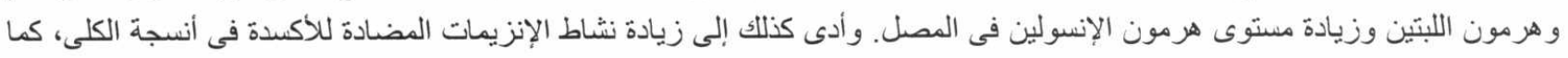

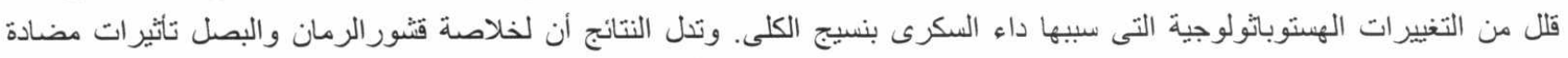

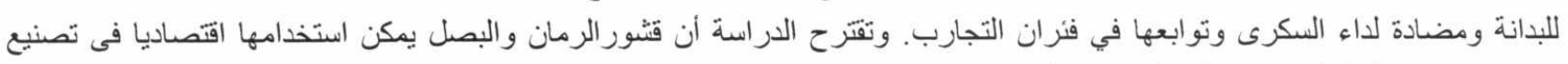

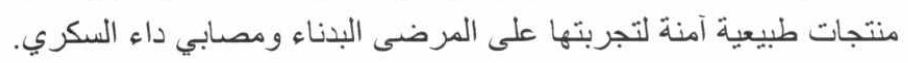

